\title{
Albert B. Steinberger: President Grant's Man in Samoa
}

\section{Stephen W. Stathis}

Among the most controversal appointments within the prerogative of American Presidents have been special emissaries in foreign relations. They are subject neither to Senate confirmation nor to authorization by law. Despite several lengthy debates in the Senate and considerable scholarly discussion on the constitutionality of these appointments, ${ }^{1}$ Presidents continue, as they have since George Washington, to appoint such special emissaries as they wish, giving them such rank and title as they deem appropriate. Elmer Plischke suggests several reasons why a President employs special representatives in diplomatic activities:

Sometimes the Chief Executive needs to rely upon someone in whom he reposes special personal confidence, who affords a more direct means of conducting United States foreign relations, who possesses great personal stature, or who enjoys special qualifications for particular tasks and is uninhibited by restraining niceties of protocol or the labyrinth of diplomatic bureaucracy. As long as Presidents are inclined to assume personal direction over foreign relations, especially in times of crisis, doubtless they will continue to appoint such individuals, who speak with the immediate authority of the White House and who are able to cut through inhibiting traditions and the limitations of ordinary diplomatic practice. ${ }^{2}$

Few of these appointments have proven more provocative and intriguing than Albert B. Steinberger's as Special Agent in Samoa during the Grant Administration. Although several scholars have chronicled Steinberger's diplomatic activities, not even the most comprehensive studies have provided an insight into the man himself. Little also has been written on the reaction of the press in America to the events associated with his extraordinary career.

Stephen W. Stathis is an analyst in American history with the Congressional Research Service of the Library of Congress. He wishes to express his appreciation to his colleague William R. Tansill for his generous help and suggestions in the preparation of this article. 


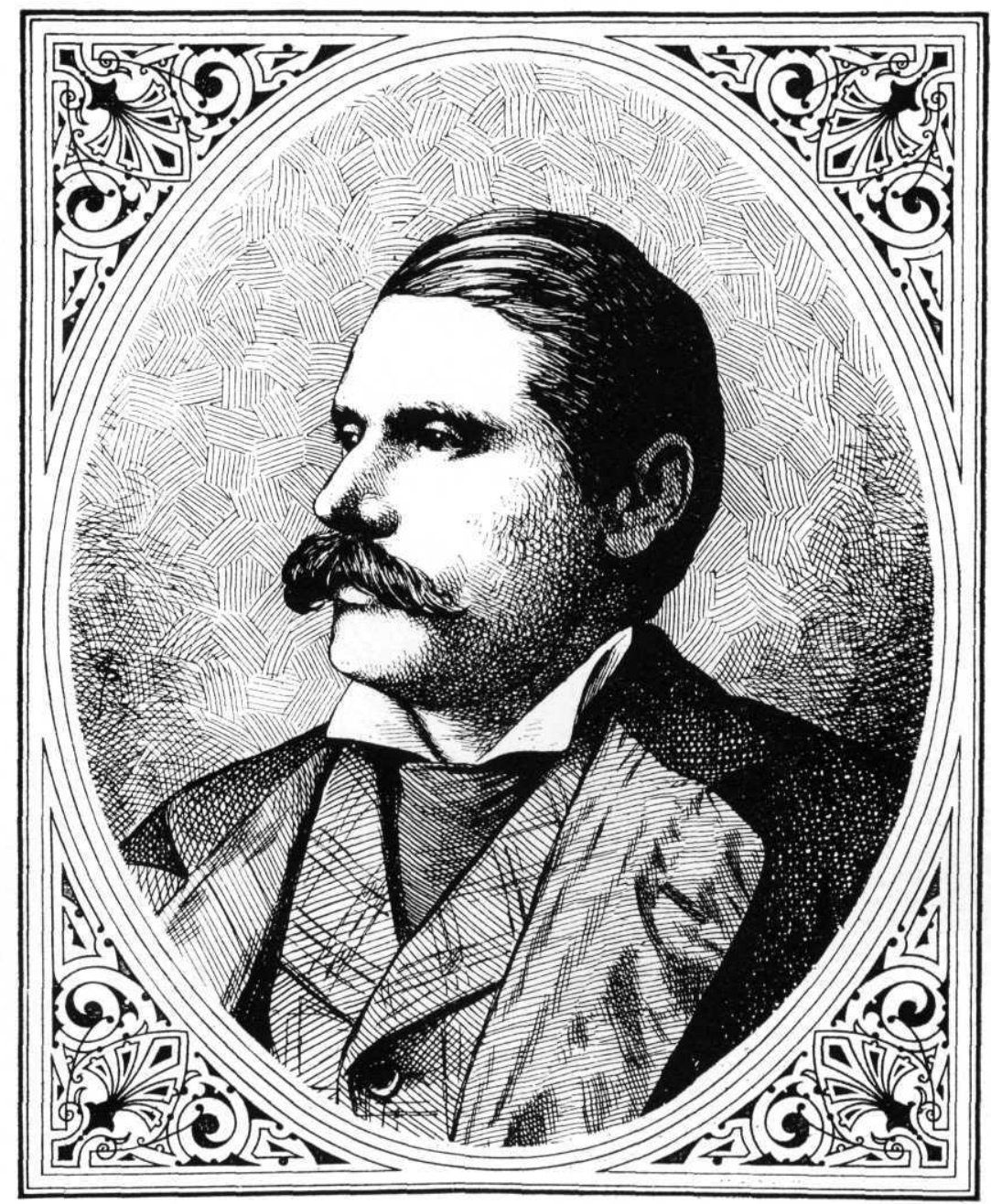

Albert B. Steinberger. Reproduced from the New York Daily Graphic, August 4, 1875 , p. 254 by the Library of Congress. 

When San Francisco's Daily Alta California first revealed ISteinberger's appointment in May I873, he was depicted as "a man of bright, keen intelligence, and [one who] possesses a bright eye that sees everything." President Grant's decision to send Steinberger to the Sandwich (Hawaiian) Islands to feel their "pulse on the subject of annexation to the United States" was viewed with considerable enthusiasm. His selection, the Alta assured its readers, would "give general satisfaction" for he was "well suited to the work before him and will no doubt create a favorable impression wherever he goes. His judgment will ensure the production of a report that will be considered reliable and worthy of careful attention."3

The following morning, the Alta's readers learned through an interview with Steinberger that he had traveled as far west as Cheyenne, Wyoming with President Grant and was actually on his way to the Navigator (Samoan) Islands. Although he declined to reveal the purpose of the visit, Steinberger did express astonishment that anything had been learned of his mission since "he thought no one outside of the Cabinet had any knowledge"4 of it.

The secrecy surrounding Steinberger's planned investigation was understandable. Although the United States had appointed American citizens as consuls in Samoa since 1852, and naval officers had explored and surveyed the islands, an official treaty had never been negotiated between the Samoan people and the United States. Now, many Americans strongly believed, was the time for the United States to become dominant along the South Pacific trade routes.

Despite considerable support among officials in the Grant Administration, the native Samoans, and the maritime community, proposals providing for an advantageous relationship with the Islands (a logical location for a maritime way station, as well as a coaling depot for the American Navy) had repeatedly been rebuffed by a reluctant Senate. Meanwhile, England, Germany, Australia, and New Zealand had begun their own schemes for controlling the Islands. ${ }^{5}$ It is in this setting that Albert B. Steinberger appeared.

\section{EARLY VENTURES}

From his birth on Christmas Day I 840 until he was fifteen, Steinberger, the sixth of nine children of a country physician, lived with his family in Schuylkill County, Pennsylvania. In $185^{6}$ his parents moved for a time to Council Bluffs, Iowa, and then eventually settled in Bellevue, Nebraska, near Omaha. ${ }^{6}$ 
Just before he turned nineteen, Albert set out for Cherry Creek, Colorado, where gold had recently been discovered. During the ensuing two years, he gained momentary notoriety first as a politician and then as Colorado's first playwright. Soon after arriving in Colorado, in November I 858 , he became one of the two men selected to secure a charter from the Territorial Legislature for the proposed townsite of St. Charles which would soon become Denver. ${ }^{\text {? }}$

Denver's Apollo Hall was the scene a year later of his four-act melodrama, "Skatara the Mountain Chieftain" which was written to celebrate the newly created "Territory of Jefferson," a popular government of short duration that preceded the legally constituted Colorado Territory. "Skatara" received less than an enthusiastic response from theater patrons, but subsequently became very popular among the miners when it was rewritten as a burlesque. ${ }^{8}$

Early in the 1860 s, Steinberger returned to the East, spending much of his time for the next decade in New York when his business ventures did not demand that he be elsewhere. In 1867 he married Caroline Lydia Ely, a daughter of Alfred and Caroline Ely of Rochester, New York. Caroline died in September 187I, after a lengthy illness following the birth of their only child. ${ }^{9}$

His most intriguing sojourn prior to his "Mysterious Mission" to Samoa took him to Paris for a personal interview with Napoleon III which, supposedly, enabled him to negotiate a large contract for a syndicate to provide the French with arms and ammunition during the Franco-Prussian War. Before the contract was completed, financial problems arose, and Steinberger became involved in a politically motivated congressional investigation focusing on the Grant Administration's alleged violations of the neutrality laws. The inquiry itself never really amounted to much, but his personal loss was considerable, and he continued unsuccessfully to press his claims against the French until his death. ${ }^{10}$

\section{APPOINTMENT TO SAMOA}

Steinberger's actual appointment by Secretary of State Hamilton Fish on March 29, 1873, as an "intelligent special agent" responsible for observing and reporting on the political and commercial conditions in the Samoan Islands, ${ }^{11}$ culminated seven months of anxious waiting. Fish first discussed the prospects of such a visit with President Grant on August I7, I872. Three days later, Fish was advised by Horace Porter, the President's Secretary, that the prominent New York shipping magnate William $\mathrm{H}$. Webb strongly recommended Steinberger "as a 
competent person to visit the Navigator Islands" and "report upon their conditions with a view of sending such information to Congress." 12

It apparently was Webb's hope that Steinberger's findings would: (I) help him finally obtain a congressional subsidy which would supplement the one he had already obtained from New Zealand for the operation of his steamer line between San Francisco and Australia, and (2) prompt the Senate Foreign Relations Committee to recommend approval of the agreement Commander Richard W. Meade, of the United States Navy, had entered into with Chief Oau O Mauga of Pago Pago early in 1872 , whereby in exchange for American protection the "latter granted the United States exclusive privilege of establishing [in Pago Pago] harbor a naval station for the use and convenience of the vessels of the United States government." 13 President Grant's opinions on these matters were already a matter of public record. In his annual message in December of 1871 he had recommended that Congress provide financial assistance for Webb's South Pacific venture. ${ }^{14}$ His message of May 22, I872, which accompanied Meade's agreement, concluded by recommending with some modification its favorable consideration by the Senate. ${ }^{15}$

Ironically, by the time Steinberger actually received his appointment "Webb had given up the fight for a United States mail subsidy and, with it, his Pacific shipping service, on which he had incurred substantial losses." ${ }^{16}$ Despite Webb's detachment from the project, President Grant remained deeply interested in obtaining suitable harbors in the Islands for the United States Navy, and thus Steinberger's adventures began. $\mathrm{He}$ embarked from San Francisco on June 29, I873. En route he spent several days in Honolulu, where the speculation in the San Francisco newspapers regarding his mission had preceded him. To avoid future misunderstanding, Steinberger soon after landing there met with his Majesty King Lunalilo at his cottage at Waikiki to assure him that he was "in no wise accredited to his government, and that the news-venders in this, as in many other cases, were irresponsible agitators." In early August Steinberger finally arrived in Samoa ready to begin one of the most intriguing episodes in America's territorial expansion. ${ }^{17}$

According to the instructions forwarded to him by Secretary Fish, he was to direct his attention specifically toward determining the number of islands constituting the group, the number of native and foreign inhabitants, the nature and quality of products grown and produced there, and those harbors suitable for ocean-going vessels. Fish suggested in his correspondence that it was "not unlikely that perhaps in the not too distant future the interests of the United States may require not only 
a naval station in the Samoan group, but a harbor where [commercial vessels] also may freely and securely frequent."

As a result "full and accurate information" would be necessary to enable the Administration to determine what means would "be advisable toward obtaining that objective." It was suggested that Steinberger, in the course of his conversations with the various chiefs in the islands, "caution them against making grants of their land to individual foreigners." He was also cautioned "to avoid conversation, official or otherwise, with any persons respecting relations between [the United States] and any other country." In addition, Steinberger was reminded of the fact that he was "not a regular diplomatic agent, formally accredited to another government, but an informal one, of a special and confidential character, appointed for the sole purpose of obtaining full and accurate information."18

Conditions in Samoa when Steinberger "anchored in the harbor of Pago Pago" on August 7, 1873, were highly conducive to his type of diplomacy. Between April 1869 and August 1870 and again from February 1872 to May 1873 Samoa had experienced a devastating civil war "among the paramount chiefs vying for interisland supremacy." 19 Just prior to Steinberger's arrival the Samoans had grown tired of fighting among themselves. Steinberger's charming manners and endless vigor, coupled with the fact that he represented a powerful government, helped him almost immediately to captivate native and foreigner alike. He became in a relatively short time the most sought-after voice in the proceedings accompanying the drafting of the first Samoan Constitution and Code of Laws. With Steinberger's influential assistance the Constitution was promulgated on August 21, $1873 \cdot{ }^{20}$

A little more than a month later, Steinberger sailed from Apia having completed his initial mission to the Islands. Before he left, however, he told his newfound friends they were "brave, earnest, and honest people," a people who believed in America and hoped for guidance from it. Although Steinberger conceded he could promise them nothing from the United States, he would express their high hopes to his government. ${ }^{21}$ In the subsequent report of his experiences prepared for Secretary Fish, Steinberger claimed that Samoans felt for the first time that "they had met a white man other than the missionaries who advised them against the sale of their land and mingled freely with them without sinister motives." 22 While such an appraisal appears self-serving, Steinberger's own opinion of his accomplishments during August and September 1873 was not an isolated one. 
Reverend S. J. Witmer and Reverend George A. Turner, chairman and secretary, respectively, of the Samoan District of the London Missionary Society, in reflecting upon Steinberger's achievements, told him that they would be "most happy" to see him return as the "first United States representative . . . feeling sure, from what we have seen of you, that you will do justice to the Samoan people, and aid them in every possible way, in all their laudable efforts for social and political improvement." Turner, in another personal letter to the departing visitor from the United States, wrote that his "honest, kindly spirit" had won him "esteem and love, and you leave with the hearty good wishes of the entire native population." ${ }^{23}$ A member of the Wesleyan Missionary Society, Reverend George Brown, in somewhat different language, praised Steinberger for his steadfast devotion to learning everything possible about Samoa and its people. Father L. Elloy, the Roman Catholic Bishop in Samoa, congratulated him for the wisdom he had shown in fulfilling his delicate and important mission. ${ }^{24}$

Native Samoan leaders, too, were lavish in their appreciation of Steinberger. On October 3, 1873 , the Ta'imua, the council of seven paramount chiefs which headed the newly organized government, and the Pule, a group of high "orators" who, among other functions, were to "see that the laws were executed," drafted a letter to President Grant endorsing Steinberger's objective, which they perceived as a plan to bring about a union between the government of Samoa and America. To facilitate this process it was their expressed desire to have Steinberger return to Samoa because the "peacefulness and the amiability of this gentleman [were] truly marvelous." 25

Steinberger returned to San Francisco the following December. A month and a half later he sent Secretary Fish a lengthy report of his findings, and twenty-seven relevant documents. Growing impatient after some three weeks of silence, Steinberger finally wrote Fish on March 4, 1874, "hoping for an expression of the sense of the [State] Department and the Government" regarding his efforts in Samoa. "I am earnest in my desire," he wrote, "to serve the Samoan people, and feel a sense of obligation to them, forseeing also the great advantage to our Government." That same day, Fish informed him by letter that his report had "been read with lively interest. It is replete with novel and valuable information, and shows that you must have been a diligent and judicious observer." ${ }^{26}$ Fish's correspondence contained no suggestion whatsoever regarding how or if the information Steinberger had gleaned would be a guide to future government policy. 
A few days after Steinberger's report was forwarded to the Senate by President Grant on April 21, the New York Daily Tribune deemed it important enough to warrant reprinting. ${ }^{27}$ "The charms of the tropical scenery, perennial fruits, and a confiding, half clad, dusky population," the Tribune suggested in an editorial a few days later, "have long exercised a singular fascination over the official mind, and what may be called the banana principle in politics has become a recognized influence in our political affairs." This policy has prompted "some of the most charming idyls in the literature of Public Documents." Steinberger, however, found in these "Fortunate Isles, just under the equator, more beautiful things than any other Special Agent ever had before, even in the balmy paradise of the West Indies, or in the spice-scented shores of Russian America [Alaska]."

More importantly, argued the Tribune, these islands are "in the direct track of commerce between San Francisco, Honolulu, and the South American ports on the one side, and New Zealand and Southern Polynesia; and as a station for coaling and supplies it would seem to be exactly what we require." Despite all this it is "by no means certain that we should gain by the establishment of a protectorate enough advantage to pay us for the trouble, jobbery, and political complications inevitably involved." In the American "system of government there is no place for protectorates or colonies." 28 Others, including Congress, were of a similar mind, and Steinberger's report was soon forgotten. ${ }^{29}$

\section{REAPPOINTMENT}

Despite the lack of any encouragement from Washington, Steinberger continued to bombard Secretary Fish with proposals which would allow him to return once again to Samoa. ${ }^{30} \mathrm{He}$ also "approached the Navy Service chief, Admiral David D. Porter, who indicated that he would speak with [President] Grant about what might be done." Another useful ally was Orville Babcock, the President's secretary. ${ }^{31}$ Finally, on August 17, 1874, President Grant informed Fish by letter that he wanted Steinberger to return to Samoa and be commissioned "with such powers as may be consistent with law and the best interests of the country." Steinberger, the Secretary of State was told, contemplated a "short visit to Europe, the object of which he would explain" as soon as he could meet with him. ${ }^{32}$

On November 19 Steinberger, by letter from Baltimore, once again emphasized his dedication to the interests of the Samoan people and assured the Secretary of State of their "devotion to make Samoa valuable, creditable and popular." Under his direction, he promised the 
"great resources of the islands [would] be quickly developed." He had already "conferred with Messrs. Godeffroy [the owners of the largest commercial interests in the South Pacific]," at Hamburg, "and received their assurance they would help secure German recognition of the Samoan Government immediately upon his arrival there." It would be advantageous if he had "such diplomatic powers as would give him precedence over the American and other consuls." He further suggested a "few presents such as two small guns, (brass), a Gatling gun, a I2-pounder Parrott, to give dignity to their government house; also a small lot of light clothing and small arms for guards, and such stationery as the Department (if in accordance with law) could furnish." 33

Steinberger's persuasive powers were not to be denied. On December II, 1874, he was authorized to return to Samoa as a "special agent of the United States." He also learned that Secretary Fish, after reading his report and reviewing information received from other sources, had become convinced of the natural fertility, important resources, and strategic importance of Samoa. Fish, however, questioned "whether these considerations would be sufficient to satisfy our people that annexation of [the] islands to the United States is essential to our safety and prosperity." Amidst this uncertainty, Steinberger's activities were to "be limited to observing and reporting upon Samoan affairs, and to impressing those in authority there with the lively interest which" the United States had in their happiness and welfare. Steinberger also was to carry with him a letter from President Grant to the Samoan leaders together with a number of gifts including several guns, ammunition, roo sailor uniforms, 3 United States flags and extra bunting, and some band instruments. ${ }^{34}$

Although Steinberger was to serve without pay as he had in 1873 , there are clear indications that other personal considerations made the prospects of a second visit to Samoa potentially a financial bonanza. His earlier discussions with the Hamburg firm of John Cesar Godeffroy \& Son were considerably more self-serving than he had led Secretary Fish to believe in his correspondence of November 19. Evidence has not been discovered even remotely suggesting Fish knew Steinberger had, on September 16,1874 , more than two months prior to his appointment as a Special Agent, negotiated a secret contract with the German firm. According to that agreement Steinberger was to promote the interests of Godeffroy \& Son by helping to establish a stable government in the Islands and then by working to ensure that the German firm obtained a virtual monopoly over trade and finances there. For his efforts Steinberger would receive a $10 \%$ commission for all materials which the 
Samoan government purchased from the firm, and a 10\% commission for all products sold to it by the Samoans. ${ }^{35}$

In addition, Steinberger on January I8, 1875 , some three weeks prior to his departure from San Francisco, entered into an agreement with John H. B. Latrobe, Jr., of Baltimore wherein the latter agreed to accompany Steinberger to Samoa and provide assistance in carrying out whatever he might negotiate there. Latrobe also agreed to assist Steinberger in establishing and organizing a government in the islands that would prove beneficial to both parties. Once Latrobe had reimbursed Steinberger the thirteen thousand five hundred dollars which the latter had incurred as debt in connection with their business arrangement, Latrobe would be entitled to twenty-five percent of all commissions and pecuniary profits of every description from all undertakings in which Steinberger might engage.

Latrobe also was to receive suitable quarters and subsistence; transportation for himself and his personal effects from San Francisco to Samoa; and twenty-five percent of any compensation he might receive from the United States Government for past or future employment in connection with Samoa." Besides financial considerations, Steinberger also agreed to "use his influence, both official and personal to procure for ... Latrobe the best and most honorable and lucrative office" in whatever government he might establish after first providing for himself. ${ }^{36}$

Both the Godeffroy agreement and the subsequent contract negotiated with Latrobe suggest by their existence that Steinberger's motives at the very least were highly suspect at this point in time. These are clear indications that Steinberger embarked on his second adventure in Samoa determined to make every effort possible to establish himself in a favorable economic and political status as soon after he arrived as possible. Once he gained such a position, he was apparently convinced he could hold it for as long as he desired.

Upon his return to Samoa on April r, 1875, after sixteen months in the United States, Steinberger found political conditions radically changed. During his absence the government he had helped establish had proven not to be as satisfactory to the natives as one with a king at its head. Unable to choose a single king, the chiefs of the various Samoan districts decided to elect two kings, Malietoa Laupepa and Pulepule, who were members of rival families. On January 2, I 875 , the two kings were jointly vested with that office and title. Almost immediately thereafter Samoa once again drifted toward another civil war. $^{37}$ 
Steinberger's arrival amidst these conditions was greeted with jubilant delight by the natives, and an elaborate festival and "fono" [assembly] were held in his honor. During the next several weeks Steinberger traveled aboard his private schooner, the Peerless, to the various islands where he met with several chiefs regarding a new constitution. Throughout all of the preliminary discussions preceding the formal adoption of a new Constitution on May I8, Steinberger repeatedly declared his intention of remaining in Samoa. Undoubtedly such expressions strongly influenced Samoan reunification. Adding to the stature of Steinberger's activities were the actions of Captain Henry Erben, Commander of the U.S.S. Tuscarora, who, after depositing Steinberger at Apia, remained in the harbor in a supportive posture while at the same time undertaking general judicious inquiries. Erben's actions "added to the local impression that Washington had adopted a more far-reaching policy of intervention than that in force in Samoa prior to Steinberger's return." 38

The constitution proposed by Steinberger and subsequently adopted provided for a legislative branch having two houses, the Taimua and the Faipule; a king to be chosen every four years alternately from the "two great houses of Malietoa and Tupua;" and a premier who would act as a counselor to the king. Together the two houses of the "parliament" were authorized to levy and collect taxes, to pay debts, to provide for the common defense and general welfare, to borrow and coin money, to regulate foreign commerce, and to build post offices and roads. The king was sovereign of the people and the chiefs; responsible for the direction of the army and the implements of war, of public lands and the poll and land taxes; chief judge of the supreme court; and executer of laws and treaties. His most important appointment, the "Premier of the Kingdom," was to "transact for the king all business connected with the special interests of the kingdom; and all documents and business executed by the premier" were to have the same "force as though executed by the King's authority." The King could not act in any official capacity without the knowledge of the premier. The premier also could participate in floor debates in both Houses, and was the presiding officer of the upper chamber. ${ }^{39}$

\section{PREMIER OF THE KINGDOM}

Malietoa Laupepa, the first King chosen under the new constitution, soon after his selection offered the premiership to Steinberger, who at the time was still an American citizen and a special agent of the United States government. On July 4, I875, Steinberger informed Secretary of State Fish that he had "accepted the position of premier of the kingdom, 
but publicly announced that, as an American citizen, [he] could receive no pay, emoluments, or title of nobility." $\mathrm{He}$ also asked for the assistance of the State Department "in the passage of a bill by Congress permitting [him], as an 'American citizen,' to hold office ... under a foreign government." In his concluding remarks, Steinberger wrote: "So much does America fill the hearts and minds of these people that any treaty for harbors, naval stations, coaling-depots, or other privileges [drafted] in Washington would receive prompt recognition here."40 Although Steinberger's letter was received on August 30 , neither a response nor a request for his resignation as a special agent followed. Subsequently, on October 28 , he officially forwarded Fish his resignation. ${ }^{41}$

At least one author has argued that Fish took no official action against Steinberger following his selection as Premier because he was waiting for Steinberger's response to charges that during his first mission to Samoa he had assumed and exercised unauthorized power inconsistent with his instructions from the State Department. ${ }^{42}$ Such an interpretation is not substantiated by fact. For more than a month prior to the receipt of Steinberger's letter announcing his selection as Premier, several major American and Hawaiian newspapers had published stories of his appointment. It is inconceivable to think that these articles were not discussed at the State Department. A more plausible explanation is that Steinberger's new title was a source of extreme embarrassment to the Department. It was thought by most journalists that he had already resigned, ${ }^{43}$ and several major newspapers had enthusiastically exposed the story as yet another Grant administration bungle.

The World of New York City, for example, envisioned "one of the first duties of the Democratic House of Representatives" after it convened in December would be "to ascertain the extent to which the funds and the property of the United States have been lawlessly lavished upon [the] scandalous and shameless speculation" in Samoa. ${ }^{44}$

San Francisco's Daily Examiner suggested in an editorial entitled: "Grant Establishing Slavery," that there was "immense speculation" that it was the object of Steinberger and Captain Erben to compel the Samoans to raise sugar and cotton, working them "just as a California miner does a rich 'lead,' or as the Southern planters formerly worked their Negroes." 45 Others such as the New York Times and Frank Leslie's Illustrated Newspaper viewed events in Samoa as yet another misuse of "Manifest Destiny," while the New York Sun considered the Steinberger incident a creation of the "active brain of [President Grant] the potentate of Long Branch as a counter check to British rule in the island 
cluster of Oceania." 46 Whether Steinberger cared or even knew about the controversy his appointment as Premier generated is not known.

Meanwhile, in Samoa Steinberger during his first few months as Premier was "self-denying, earnest, and enthusiastic in his efforts to ameliorate the conditions of the people, and to raise their government and country to the dignity and independence of a well-ordered and independent nation." $47 \mathrm{He}$ was also able to secure the support and cooperation of the missionaries in several of his endeavors. His manner proved to be quite different from that anticipated by most American journalists and suggested in the contracts he negotiated just prior to his departure for Samoa. Unfortunately, it probably will never be known whether Steinberger's posture was contrived or real.

\section{DEMISE}

Little time elapsed before Steinberger's policies began to arouse the enmity of those whites in Samoa who felt he had gone too far in his desire to protect the rights of the natives. Many English and German residents were apprehensive regarding Steinberger's threat to investigate land claims, and concerned that he might through subtle conversation divert Samoan trade toward the United States. Moreover, Great Britain's motives were at least in part the result of the annexation notions of New Zealand and Australia. A willing supporter of the English and German charges, United States Consul to Samoa S. S. Foster had himself long sought to have Steinberger removed. Jealousy of "Steinberger's influence as well as his threat to block foreign land schemes with which Foster was allied, probably caused the friction between" the two men. Foster, even before Steinberger's arrival in April, complained to the State Department of a tendency on the latter's part to assume unwarranted powers. $^{48}$

Not until December I7, however, did Foster take matters into his own hands. On that day, a few minutes after 8 a.m., Foster boarded Steinberger's yacht, the Peerless, which was anchored in Apia harbor, and "seized her in the name of the United States. ... At the time of the seizure the crew consisted of two hands and a cook." Steinberger was not on board, having left the vessel a few moments earlier. Subsequently, Foster, with the assistance of several men from the British man-of-war Barracouta commanded by Captain Charles E. Stevens, removed a portion of military equipment and arms stored aboard. At the same time Foster took possession of Steinberger's personal belongings including some of his correspondence. The seizure culminated several consultations between Foster, Captain Stevens, who had arrived in Apia on 
December I2, S. F. Williams, the British acting consul, and Dr. George A. Turner of the London Missionary Society. ${ }^{49}$

Four days after the seizure, Steinberger forwarded a formal protest to Foster for his "illegal, unnatural, and wanton despoiling and dismantling" of the Peerless. Similar complaints which had been sent to Captain Stevens some hours earlier were attached. The same day that Steinberger rebuked Foster, King Malietoa wrote to the United States Consul demanding the immediate return of the "arms and ammunition seized and taken from the yacht Peerless." ${ }^{50}$ These protests were followed by three meetings on December 24, 27, and 29 between Captain Stevens and King Malietoa, and several others including Foster, Williams, and Steinberger. For the most part these proceedings centered on the authenticity of Steinberger's credentials as a representative of the United States, and the motives prompting his residence in Samoa.

Discussion during the first meeting focused on Steinberger's alleged inability to exhibit credentials from the United States government granting him the degree of authority he had been exercising. During the second session a long, heated exchange between Steinberger and Stevens concluded only after the two antagonists were finally interrupted by King Malietoa's declaration that if Steinberger had "done anything wrong or had violated his oath, it was the business of [the Samoan] government. ... [We are] responsible for his acts, and [we] do not consider that he had violated his duty." More important, the Samoans did not want foreign representatives interfering in their governmental matters. ${ }^{51}$

The final session of December 29, centered on a speech prepared by King Malietoa the English translation of which was read aloud for the first time on this occasion. Malietoa in this statement explained that he considered Steinberger "neither an adventurer nor a schemer, but . . . a gentleman whom we requested the President of the United States to send to us, in our petition to him, to assist us in establishing our government." It was in accordance with that petition that Steinberger was allowed to return to Samoa:

\footnotetext{
We were aware of everything that transpired in reference to Colonel Steinberger before we appointed him premier of our government. We did not wish him to have a commission from the United States of America to establish our government; he has taken the oath of allegiance to our government, and we will protect him. We would now this day demand of your excellency what is the meaning of this examination of our premier? Who is it that doubts he is our premier; which of the consuls is it that does not know he has been appointed by us ? 52
}

Stevens in response warned that if the Samoans continued to support Steinberger, their laws and taxes would cease to be applicable to British 
subjects. Immediately thereafter, the King, the Taimua, and the Faipule following a brief consultation "agreed to stand by and support Steinberger at all hazards." 53

During the next two weeks the continuing controversy between the Samoan government and the British and American consuls aroused virtually everyone's interest and comments. ${ }^{54}$ Samoan support of Steinberger, however, remained virtually unchanged. Then, on January 13, 1876, Stevens and his associates (which by this time also included Alfred L. Poppe, acting German consul and an agent of J. C. Godeffroy \& Son), issued a proclamation declaring foreign inhabitants would be withdrawn from the jurisdiction of the Samoan government. King Malietoa's stinging protest of the following week fell on deaf ears. ${ }^{55}$ Meanwhile Stevens, together with the British and American consuls, was busy scheming Steinberger's removal. On the evening of February 7 , King Malietoa, while on board the Barracouta, was pressured into signing a letter stating that Steinb erger was the cause of the confrontation between the Samoan government and the foreign officials, and his immediate removal was imperative. The following morning Malietoa announced to the Taimua and Faipule that he was removing Steinberger as premier. Steinberger's departure, Malietoa assured his fellow Samoans, would not alter their interest in securing bona fide protection from the United States. Until the United States expressed an interest in such an arrangement, he would rely on the British government for protection. Following the King's remarks, Steinberger was placed under arrest by Stevens and jailed aboard the Barracouta. ${ }^{56}$

That same evening an outraged Taimua and Faipule forced King Malietoa to resign and removed him under guard to another island. Subsequent efforts by Captain Stevens and the American and British consuls to reinstate Malietoa finally erupted on March 13 into open fighting between the sailors of the Barracouta and native Samoans. During this skirmish four sailors and three Samoans met their deazh before the natives finally surrendered.

A few days later the Barracouta sailed from Apia for Auckland, New Zealand carrying as prisoners Steinberger and Jonas M. Cole, a former consul at Samoa, who, after the former's arrest, was accused of being the principal influence in thwarting the efforts to reinstate King Malietoa. ${ }^{57}$ John H. B. Latrobe, who, through Steinberger's efforts had been able to secure the titles of secretary of war, chief justice, treasurer and private secretary, and commander-in-chief of the Samoan army and navy, was put on another ship and sent home to Baltimore. ${ }^{58}$ 
The following week Steinberger and Cole were released at Levuka, Fiji after Sir Arthur Gordon, the British governor there, informed Captain Stevens that his actions in Samoa had been most improper. Steinberger immediately embarked for Auckland after having learned court-martial proceedings against Stevens were to be held in that city. When he arrived there, however, he found that the entire matter would be referred to the home office. ${ }^{59}$ Although Great Britain never did assume responsibility for Captain Stevens' actions since he had allegedly acted at the request of the United States consul and the King of Samoa, ${ }^{60}$ Steinberger received a vindication of sorts when Captain Stevens was compelled to resign his commission, and consuls Foster and Williams were removed from office by their respective governments. ${ }^{61}$

In the late spring and early summer of 1876 , after news of events in Samoa finally reached other islands in the South Pacific and beyond, there was considerable public discussion of what it all meant. Papers in New Zealand were generally quite critical of Captain Stevens' actions, while the Australians and British were far less sympathetic toward Steinberger ${ }^{62}$ In the United States, the New York Times and the New York World assumed the lead in denouncing President Grant's special agent. The World of March 12, I876, characterized Steinberger as "Grant's disreputable friend and protege." An "adventurer" who abused the "American flag in the most open and insolent manner," he was a person whose actions should be the subject of a House of Representatives inquiry. "It is bad enough to have to bear the burden of Belknapism in our home affairs, but this Pacific job threatens to emit a stench which cannot be stifled within our own borders." The sooner this matter is resolved, "the better it will be for the country." ${ }^{33}$ Again on April 20, the World in a lengthy editorial entitled "Steinberger's Downfall" called for a congressional inquiry of the whole affair. ${ }^{64}$

Suggesting provocative side issues to a possible congressional inquiry, the World in late April and early May repeated the widespread rumor of a corrupt arrangement between Steinberger and the President's confidential secretary Orville Babcock, who only a few months earlier had barely escaped conviction for alleged involvement in the whiskey rings. At approximately the same time, the World also published a story from the San Francisco Chronicle which traced Steinberger's downfall to love of a Samoan Princess, Safua. ${ }^{65}$ Using an entirely different tactic, the New York Times on May 5 argued: "there never was . . . any good reason why Steinberger should have been sent to the Samoan Islands, or have been permitted the quasi sanction of the government in his ridiculous intrigues in the South Pacific." His failure had jeopardized 
the "prestige of the Republic . . . in the South Pacific." 66 "Steinberger's career," Nation magazine remarked on April 27, "appears to have been that of what is popularly known as a 'fraud.' There was no reason for sending him to" Samoa. His activities there were a "pure farce, and the wonder is how Steinberger got anybody to play it with him." 67

Criticism of the Steinberger affair, however, was not all one-sided. The March 12 New York Sun in even stronger language suggested that President "Grant should at once ... recall the United States Consul, and declare war against the powers whose consuls joined with him in discrediting Steinberger's edicts." "By what right," asked the New York Herald two weeks later, "did the Captain of a British ship take possession of Steinberger's navy?... Certainly America can protect her own dignity." Although the Herald did not believe that Steinberger's enterprise in Samoa was legitimately American, he was entitled to American protection; "it is not pleasant to see the British officers hauling down American flags and kicking American citizens as though they were Hottentots or kings of Delhi. The President should look into the business and see what it means." 68

Using similar language, San Francisco's Daily Alta California of May 7 questioned Stevens' right to "interfere with the Government of Samoa; to make or unmake Kings; to land a couple of hundred of his men; to attempt to disarm the people, and to murder them if they refused?" Such actions, the Alta declared, were more than adequate grounds for a congressional inquiry. Emphasizing the economic implications of the Barracouta incident, the Alta on April 24 asked, "Why is it that the people do not awake to the fact" that if we let the British take Samoa we are losing a "trade that can be diverted to [San Francisco], instead of being carried on directly with Europe-a trade that is valuable to us, to say nothing of the great" opportunity these Islands would provide for a coaling-station in the South Pacific. ${ }^{69}$

Meanwhile, as the Steinberger controversy continued to be badgered about by the press, the State Department was the recipient of several conflicting reports from Foster, Steinberger, and others which further confused the issues at hand. Assistant Secretary of State William Hunter learned from a letter Foster mailed on March $18, \mathrm{I} 876$, that the latter had found several important documents among Steinberger's possessions following his arrest. Included among these papers was a contract between the Godeffroy firm and Steinberger which fully explained "his course [of action in Samoa] against the foreigners, and particularly his envenomed course towards the American consul and American citizens."70 A month and a half later, Steinberger informed Secretary Fish that his 
agreement with John Cesar Godeffroy had been: (I) drafted specifically for the benefit of the Samoan people whose government the Hamburg firm pledged to induce the German imperial government to recognize, (2) consummated prior to his becoming an official of either the United States or Samoan governments, and (3) "abrogated by mutual agreement between Mr. Alfred S. Poppe at Samoa for J. C. Godeffroy \& Sons, and [Steinberger] a few days after [his] arrival, and such notification was given to the house in Hamburg."71

The sincerity of Steinberger's efforts, the Samoan Taimua and Faipule assured President Grant in a May I, I876, letter, could not be questioned. Those responsible for his downfall had acted against the will of the Samoan people. "Therefore," the Samoan legislature announced "we declare now to Your Excellency that we wish still to have Colonel Steinberger as our premier, because he has done right with a true love and great patience." If it was the President's intention not to allow Steinberger to return, "we then humbly pray to Your Excellency to appoint another gentleman as good and as skillful as Colonel Steinberger to teach our government." 72

Steinberger was destined never to return to Samoa. In the years immediately following his adventures in Samoa, he unsuccessfully sought remuneration from the British government for the damages inflicted by Captain Stevens. ${ }^{73}$ Thereafter he quickly disappeared from the American scene. At the height of his momentary notoriety in 1876 the New York World quipped that Steinberger was "destined always to remain a tremendous historical figure." While it was true that he does not stir the public consciousness "in the same dignified degree that George Washington does, and FrankLin somewhat exceeds him in mild majesty of style ... he could readily clean out all the signers of the Declaration of Independence at draw-poker." 74

When Steinberger died in 1894 , however, little was remembered of his exploits except that he had been "once chosen King of the Samoan Islands " and for his efforts was "called by all kinds of names." 75 Vague references were made to Steinberger's interest "in several well-known projects among them being the Cape Cod Canal," and to his having lived in New York since his Samoan adventure. ${ }^{76}$ Even the fact that he had served as a paymaster for the United States Army was not known. ${ }^{77}$ Only the Harrisburg, Pennsylvania Patriot was able to tell its readers that Steinberger had been an "erect, handsome gentleman, under medium height, with a profusion of dark and gray hair and a heavy moustache."78 


\section{CONCLUSION}

Much of his life remains shrouded in mystery. Extensive research among the various collections of the Library of Congress, the National Archives, and the major historical and genealogical societies in New York, Pennsylvania, Nebraska, and Colorado has revealed little of Albert B. Steinberger beyond the information contained in the several hundred pages of congressional documents relating to his activities in Samoa. Although several writers have suggested Steinberger's appointment as a special agent stemmed from a close relationship with Grant and shipping magnate William A. Webb, ${ }^{79}$ documentation which would conclusively substantiate this claim has not been found. There is also no proof, as some have argued, that Steinberger was appointed because he held a $\$ 75^{\circ}$ gambling note signed by President Grant. ${ }^{80}$ How or why he obtained the title Colonel, a designation he carried for at least the last thirty years of his life, life, likewise remains a conundrum. ${ }^{81}$

Perplexing questions are likely to remain unanswered. It is clear that Steinberger as an executive agent of the United States assumed authority not granted to him by the State Department when he helped establish and subsequently became a prominent official in a new foreign government. We also know that this same man, a year after his forced departure, was still held "in a degree of esteem amounting to veneration, and [was] looked upon by [the Samoans] as the wisest and safest ruler and best friend" Samoa had ever had. ${ }^{82}$ Essentially, Steinberger's activities in Samoa were positive though not authorized.

Although there are several plausible explanations for his course of action, the issue of overriding importance is that Steinberger was a special agent of the President. Throughout our nation's history it has not been uncommon for a President to rely upon a special agent to act as his alter ego in a particular phase of foreign policy. Could such have been the case in Samoa?

Congress in 1876 and again in 1877 , despite a public outcry for a congressional inquiry into Steinberger's activities, published without a word of debate or comment several hundred pages of documents relating to the matter which it had received from the Executive Branch. ${ }^{83}$ In I 888 the Senate published as part of a minority report of the Committee on Foreign Relations a list of 438 diplomatic agents who had been sent to "negotiate and conclude conventions, agreements, and treaties with foreign powers since 1792 ," who were appointed without the advice and consent of the Senate. The report also revealed that between 1827 and I880 not one President had asked for Senate approval of such appoint- 
ments. Missing from the Committee's statistics were many other special agents such as Albert B. Steinberger, whose missions purportedly were essentially fact-finding in nature. Their inclusion would have added several hundred more names to a special category of presidential appointments which have included such illustrious personages as John Quincy Adams, James Monroe, Henry Clay, Martin Van Buren, Daniel Webster, James Buchanan, George Bancroft, Hamilton Fish, Colonel (Edward Mandell) House, Bernard M. Baruch, Wendell Willkie, and Harry Hopkins. ${ }^{84}$

"At the beginning of American history," Hans Morgenthau suggests, "the use of the special agent was primarily due to the scarcity of available talent. Later it was due to the low quality of many diplomatic representatives, chosen for political reasons and without regard for their diplomatic qualifications. More recently," in Morgenthau's opinion, "the President has availed himself of the special agent in order to make sure that his will prevails in the conduct of American foreign policy. The institution of the special agent is indeed inseparable from the preeminent, contested and uncertain role the President plays in the determination of American foreign policy." 85

Special agent Albert B. Steinberger was the product of this policy. Had his premiership gone smoothly and had Samoa become an American protectorate within a reasonable length of time, it is conceivable the Islands would have been spared a quarter century of revolution and war, and the American, British, and German governments would have avoided confrontations that, at times, nearly resulted in war.

Certainly it is unreasonable to suggest that President Grant could have predicted such a course. Nevertheless, Grant was an expansionist who was chastened after the Santo Domingo debacle and who looked upon Steinberger's activities as a trial balloon. If Steinberger's mission had succeeded, it could have provided naval and coaling facilities to complement those which later existed at Pearl Harbor. Instead, the results of his experiment constitute a part of our esoteric history, familiar only to the specialist in America's Pacific adventures.

\section{NOTES}

${ }^{1}$ Joseph Harris, The Advice and Consent of the Senate: A Study of the Confirmation of Appointments of the United States Senate (Berkeley: University of California Press, I 953), pp. 284-289; Maurice Waters, "The Ad Hoc Diplomat: A Legal and Historical Analysis," Wayne Law Review 6 (Summer 1960), 380-392; Quincy Wright, The Control of American Foreign Relations (New York: The Macmillan Company, 1922), 
pp. 31 $1-315$; Henry Wriston, Executive Agents in American Foreign Relations (Baltimore: Johns Hopkins Press, 1929), pp. I-312; and U.S. Congress, Senate, The Constitution of the United States : Analysis and Interpretation, $92 \mathrm{~d}$ Cong., $2 \mathrm{~d}$ sess., 1973, S. Doc. 92-82, pp. 52I-523 (Serial no. 12980-7).

${ }^{2}$ Elmer Plischke, Conduct of American Diplomacy (Princeton: D. Van Nostrand Co., Inc., I967), pp. 48-49.

${ }^{3}$ San Francisco Daily Alta California, 12 May 1873.

${ }^{4}$ Ibid., I2 May 1873. Steinberger's statement that he had traveled with President Grant as far as Cheyenne, while not substantiated by any additional documentation, does coincide very closely with the President's visit to the West. Denver, Colorado Daily Rocky Mountain News, 30 April I 873. Interestingly, the San Francisco Chronicle, I 3 May I 873, stated that it cou id learn nothing of Steinberger's "Mysterious Mission."

${ }^{5}$ Jean Ingram Brookes, International Rivalry in the Pacific Islands I800-I875 (Berkeley: University of California Press, 194I), pp. 318-320; Joseph W. Ellison, Opening and Penetration of Foreign Influence in Samoa to I880 (Corvallis, Oregon: Oregon State College, 1928), pp. 8-10, 29-31, 44-46; W. P. Morrell, Britain in the Pacific Islands (Oxford: Clarendon Press, 1960), pp. 213-215; Jeannette Keim, Forty Years of German American Political Relations (Philadelphia: William J. Dornan, 1919), pp. I14-I 15; Angus Ross, New Zealand Aspirations in the Pacific in the Nineteenth Century (Oxford: Clarendon Press, 1964), pp. I12-II3; George Herbert Ryden, The Foreign Policy of the United States in Relation to Samoa (New Haven, Connecticut: Yale University Press, 1933), p. I9; Mary Evelyn Townsend, Origins of Modern German Colonialism $I 87 I-1885$ (New York: Columbia University, I92I), pp. 54-58, 6o-64; and John M. Ward, British Policy in the South Pacific (Sydney: Australasian Publishing Co. Pty. Ltd., I948), p. 213.

${ }^{6}$ Sketchy details of Steinberger's early years are found in Death Record of Albert B. Steinberger, Registry of Vital Statistics, I894, v. 447, p. I08, no. 3942, Department of Public Health, Commonwealth of Massachusetts; Seventh Census of the United States, 1850 , v. 58 , Blythe Township, Schuylkill County, Pennsylvania, Records of the Bureau of the Census, Record Group 29, National Archives; and in an obituary of his father, Anthony M. Steinberger, published in the Pueblo Colorado Chieftain, 29 July I 886. Martin Torodash mistakenly gives Steinberger's date of birth as December 25, 1835 ("Steinberger of Samoa: Some Biographical Notes," Pacific Northwest Quarterly 69 [April 1977], I 5). Erroneous biographical information appears in the Denver Daily Tribune, 18 April 1876 ; and in R. W. Robson, Queen Emma (Sydney: Pacific Publications, 1965), pp. 45-49.

${ }^{7}$ Herbert Howe Bancroft in his History of the Pacific States of North America : Nevada, Colorado, Wyoming I540-1888 (San Francisco: The History Company Publishers, I 890 ), p. 403 , states that on November 6,1858 , Steinberger and Hiram J. Graham were elected as "delegates to proceed to Washington" with a petition requesting congressional approval for a separate government for Colorado under the name of the Jefferson Territory. The problem with what Bancroft has written (subsequently repeated by F. L. Paxson, "The Territory of Colorado," American Historical Review I 2 [October 1 906], 55; and J. Sterling Morton, Illustrated History of Nebraska, 2 vols. [Lincoln: Jacob North \& Company, 1905], I, 322) is that it is historically inaccurate. Although there is abundant evidence of Hiram Graham's election as a delegate to call upon Congress, no documentary evidence whatsoever has been discovered supporting the contention that Steinberger was elected as well. The most concise study of the election is Donald W. Hansel's, "The Beginning of Government in Colorado," in Curtis Martin and Wallace Steadley, eds., Readings in Colorado Government (Boulder, Colorado: Bureau of Governmental Research and Service, 1967), pp. 19-23. For other studies of the election see LeRoy R. Hafen, "Jefferson Territory and Its Competitors," in Herbert D. Beyer, ed., I945 Brand Book Contain- 
ing Twelve Original Papers Relating to Western and Rocky Mountain History (Denver: The Westerners, 1945), p. 146; Milo Fellows, "The First Congressional Election in Colorado (1858)," Colorado Magazine 6 (January 1929), 46-47; Frank Hall, History of the State of Colorado (Chicago: Blakely Print Co., i 889), p. 208; and Jerome Smiley, History of Denver (Denver: Old Americana Publishing Co., I901), pp. 305-306. Undoubtedly, one of the principal reasons for the confusion is that in the fall of 1858 , there were actually two rival camps along Cherry Creek, Auraria on the east bank and St. Charles (which later became Denver) on the west. The gold miners who elected Hiram J. Graham were Aurarians, not the "drinking and hum bugging" group Steinberger associated with in St. Charles. His election was for an entirely different purpose. See Herman S. Davis, comp., Reminiscences of General William Lairmer and His Son William H. H. Lairmer (Lancaster, Pennsylvania: Press of the New Era Printing Company, 1918), p. 105; Hensel, "Government in Colorado," p. 22; and Edward E. Wynkoop, "Edward Wynkoop," Collections of the Kansas State Historical Society 13 (1913-1914), 72.

${ }^{8}$ Although Robert G. Athearn, The Coloradans (Albuquerque: University of New Mexico Press, 1976), p. 42, feels that Steinberger "may have been Colorado's first playwright," James H. Baker and LeRoy R. Hafen, History of Colorado, 3 vols. (Denver: Linderman Co., Inc., 1927), pp. 1254-1255, credit him without reservation as being "Colorado's first dramatist." Hafen reiterates this belief in his four-volume study of Colorado and Its People (New York: Lewis Historical Publishing Co., Inc., 1948), I, 262, as does Sandra Dallas in Cherry Creek Gothic: Victorian Architecture in Denver (Norman, Oklahoma: University of Oklahoma Press, 1971), p. 247; Gold and Gothic (Denver: Lick Skillet Press, 1967), p. 6. Brief accounts of the play are found in Phyllis Flanders Dorset, The New Eldorado: Story of Colorado's Gold and Silver Rushes (London: The Macmillan Company, 1970), pp. 63-64; and Melvin Schoberlain, From Candles to Footlights : A Biography of the Pikes Peak 1859-1876 (Denver: Old West Publishing Company, I941), pp. 29-30, 32-33.

${ }^{9}$ Boston Evening Transcript, 3 May 1894; Rochester (New York) Daily Union and Advertiser, 19 September 1871 ; H. Wilson, comp., Trow's New York City Directory for the Year Ending May I, I87o (New York: John F. Trow Publisher, 1869), p. r054; and Torodash, "Steingberger in Samoa," p. 52.

${ }^{10}$ For brief summaries of the investigation see David M. Jordan, Roscoe Conkling of New York: Voice in the Senate (Ithaca, New York: Cornell University Press, 1971), pp. 175-178; and E. Bruce Thompson, Matthew Hale Carpenter: Webster of the West (Madison, Wisconsin: State Historical Society of Wisconsin, 1954), pp. 166-171. Documents and testimony relating to Steinberger's role in the investigation are found in U.S. Congress, Report of the Select Committee to Investigate All Sales of Ordinance Stores Made by the Government of the United States During the Fiscal Year Ending June 30,1871 , S. Rept. no. 183, 42d, Cong., 2d sess., pp. 88, 91, 97, 100, 102-104 46r-464 (Serial no. 1497). See also Appleton's Annual Cyclopedia and Register of Important Events of the Year I89+ (New York: D. Appleton and Company, 1895), p. 600; and Boston Evening Transcript, 3 May 1894.

${ }^{11}$ Hamilton Fish to Albert B. Steinberger, 29 March 1873, U.S. Congress, House, Committee on Foreign Relations, A. B. Steinberger: Message from the President of the United States, Transmitting a Report from the Secretary of State and Accompanying Papers, 44th Cong., Ist sess., H. Exec. Doc. I6I, pp. 5-6 (Serial no. I691; cited hereafter as Steinberger Message). A copy of the original letter is found in Diplomatic Instructions of the Department of State, 1801-1906, Special Missions (M-77), Roll 154, General Records of the Department of State, Record Group 59, National Archives (hereafter cited as Diplomatic Instructions, Special Missions, RG 59, NA). 
${ }^{12}$ Steinberger to Ulysses S. Grant, I7 August 1872; and Horace Porter to Hamilton Fish, 20 August 1872, Steinberger Message, p. 3. See also Records of the Department of State, Communications from Special Agents, I794-1906 (M-37), Roll 28, General Records of the Department of State, Record Group 59, National Archives (cited hereafter as Communications from Special Agents, RG 59, NA). Theories regarding Steinberger's appointment are found in Barry Rigby, "Private Interests and the Origin of American Involvement in Samoa, 1872-1877," Journal of Pacific History 8 (1973), 79; and Torodash, "Steinberger in Samoa," p. 52.

${ }^{13}$ Agreement between Maunga, great chief of the Bay of Pago Pago of the Island of Tutuila, residing at Pago Pago, and the Government of the United States of America represented by Richard W. Meade, esquire, Steinberger Message, pp. 6-7; and Brookes, International Rivalry, pp. 317-319.

${ }^{14}$ James D. Richardson, A Compilation of the Messages and Papers of the Presidents, 20 vols. (New York: Bureau of National Literature, Inc., I897-1912), IX, 1401.

${ }^{15}$ Message from the President of the United States, transmitting an agreement between the great chief of the Island of Tutuila and Commander R. W. Meade of the United States Navy, Steinberger Message, p. 6.

${ }^{16}$ R. P. Gilson, Samoa I830 to I90o: The Politics of a Multi-Cultural Community (Melbourne: Oxford University Press, 1970), p. 295-296.

${ }^{17}$ Report of Samoa or Navigator's Islands, U.S. Congress, Senate, Committee on Foreign Affairs, Message From the President of the United States Transmitting a Communication from the Secretary of State, and the Report by which it is Accompanied Upon Samoa or the Navigator Islands, 43d Cong., Ist sess., 1874, S. Exec. Doc. 45, p. 2 (Serial no. 1581; hereafter cited as Samoa Report); Steinberger Message, p. I3. See also Hawaii Gazette, 28 May, 16 July, and 23 July 1873.

${ }^{18}$ Fish to Steinberger, 29 March 1873 , Steinberger Message, pp. 5-6. A copy of the original letter is found in Diplomatic Instructions, Special Missions, RG 59, NA.

${ }^{19}$ U.S. Library of Congress, Congressional Research Service, William R. Tansill, America Samoa: A Descriptive and Historical Profile (Washington: Congressional Research Service, October 8, 1974), pp. 28-29.

${ }^{20}$ Ellison, Foreign Influence in Samoa, p. 53; Ryden, Foreign Policy, p. 109; Samoa Report, pp. 38, 47-51 ; and Steinberger Message, pp. 49, 58-62.

${ }^{21}$ Samoa Report, pp. 46-47; and Steinberger Message, pp. 56-57.

${ }^{22}$ Samoa Report, p. 36; and Steinberger Message, p. 47. For an amusing response to Steinberger's egotistical declaration see Commander Richard W. Meade's letter to the editor of the New York World, in May i 874.

${ }^{23}$ George A. Turner and S. J. Whitmer to Steinberger, 4 October 1873 ; and Turner to Steinberger, 7 October 1873, Samoa Report, pp. 52-53; Steinberger Message, pp. 63-64; and Communications From Special Agents, RG 59, NA.

${ }^{24}$ L. Elloy to Steinberger, 29 September 1873; and George Brown to Steinberger, September 1873, Samoa Report, pp. 53-54; Steinberger Message, pp. 64-65, and Communications From Special Agents, RG 59, NA.

${ }^{25}$ Chiefs and Rules of the Government of Samoa to Principal Chief of the American Government, 3 October 1873, Samoa Report, pp. 45-46; Steinberger Message, pp. 56-57; and Communications From Special Agents, RG 59, NA.

${ }^{26}$ Steinberger to Fish, 9 February 1874 , and 4 March 1874 , Steinberger Message, pp. 12 , 69; and Communications From Special Agents, RG 59, NA.

${ }^{27}$ New York Daily Tribune, 9 May 1874.

${ }^{28}$ Ibid., I I May 1874. 
${ }^{29}$ On May 25, 1874, Congressman Sherman O. Haughton of California introduced a resolution (H.R. 3464) "to authorize the purchase of harbor privileges and land for the establishment of a naval and coaling station in the Samoan Islands." Subsequently, the bill was referred to the Committee on Foreign Relations where it died. Congressional Record, 43d Cong., Ist sess., v. 2, pt. 5, p. $425^{8}$ (25 May 1874). An identical bill (S. 855) introduced by Senator William Windom of Minnesota was referred to the Senate Committee on Naval Affairs which several months later issued an adverse report on the proposal. Congressional Record, 43 d Cong., ist sess., v. 2, pt. 5, p. $445^{\circ}$ (2 June 1874); and ibid., v. 3, pt. 2, p. 1096 (10 February 1875).

${ }^{30}$ Steinberger to Fish, I4 March, 8 April, I7 April, and II May I874, Steinberger Message, pp. 69-75; and Communications From Special Agents, RG 59, NA.

${ }^{31}$ Rigby, "Private Interests", p. 82.

32 This correspondence does not appear among the numerous documents Congress published relating to Steinberger's activities and has been totally overlooked by scholars. Grant to Fish, 17 August 1874, Communications From Special Agents, RG 59, NA.

${ }^{33}$ Steinberger to Fish, 19 November 1874 , Steinberger Message, p. 75 ; and Diplomatic Instructions, Special Missions, RG 59, NA.

${ }^{34}$ Fish to Steinberger, II December 1874 , Steinherger Message, pp. 76-77. See also U.S. Congress, House, The Agency of A. B. Steinberger in the Samoan Islands, 44th Cong., 2d sess., 1877, H. Exec. Doc. 44, pp. 102-103 (Serial no. 1755; hereafter cited as Steinberger in Samoa Report); and Diplomatic Instructions, Special Missions, RG 59, NA.

${ }^{35}$ Grant to Fish, 17 August 1874 , Communications From Special Agents, RG 59, NA; and Agreement Between Colonel A. B. Steinberger and Messrs. John Ces Godeffroy \& Son of Hamburg, for their establishment at Apia, Steinberger in Samoa Report, pp. 128-130.

${ }^{36}$ Articles of Agreement Between A. B. Steinberger and John H. B. Latrobe of Baltimore, Md., ibid., p. 135. See also Baltimore Gazette, 22 April 1876; and Baltimore Sun, 24 April 1876.

${ }^{37}$ Gilson, Samoa 1830 to I90o, pp. 310-312; and Ryden, Foreign Policy, p. I 22.

${ }^{38}$ Gilson, Samoa I830 to I900, p. 313. See also Henry Erben, "The Tuscarora's Mission to Samoa," Century Magazine 38 (May 1889); Hawaii Gazette, 23 June I875; San Francisco Daily Alta California, 13 July 1875; and Washington Evening Star, 22 July 1875 .

${ }^{39}$ U.S. Congress, House, Committee on Affairs, American Rights in Samoa, 50th Cong., Ist sess., H. Exec. Doc. 238, pp. 194-198 (Serial no. 2560). The Baltimore Sun, 24 July 1882 , credits John H. B. Latrobe, Jr. with having "drafted the [Samoan] constitutional code of laws ... while on the voyage there."

${ }^{40}$ Steinberger to Fish, 4 July 1875 , Steinberger Message, p. 81; and Communications From Special Agents, RG 59, NA.

${ }^{41}$ Steinberger to Fish, 28 October 1875 , Steinberger Message, p. 89; and Communications From Special Agents, RG 59, NA.

${ }^{42}$ Ryden, Foreign Policy, pp. 126-130.

${ }^{43}$ For comments on Steinberger's resignation see Hawaii Gazette, 23 June 1875 ; New York Times, 22 July 1875; and San Francisco Daily Alta California, 13 July 1875.

${ }^{44}$ New York World, 16 July 1875. See also New York World, 18 August 1875 ; and San Francisco Daily Examiner, 26 July 1875.

${ }^{45}$ San Francisco Daily Examiner, 3 August 1875 . 
46 "The New American Monarchy in the Pacific: Grant and Steinberger," Frank Leslie's Illustrated Newspaper, 21 August 1875, pp. 406-407. See also New York Times, I6 July 1875; and New York Sun, 21 July 1875. For other contemporary stories on Steinberger's selection as premier see: Hawaiian Gazette, 23 June, I5 September 1875; New York Herald, I I August 1875; New York Sun, 22 July, 29 July 1875; New York Times, I5 July, 22 July, 2 September, 5 September I875; New York World, 30 July 1975; San Francisco Chronicle, 14 July, 29 July 1975; Daily Alta California, I 3 July, I4 July, 26 August I875; San Francisco Daily Evening Post, 13 July 1875 ; and San Francisco Daily Examiner, 5 August 1875 .

${ }^{47}$ Gilderoy W. Griffin to Hamilton Fish, 2 February 1877 , Steinberger in Samoa Report, p. $\mathbf{1}_{5} 6$.

${ }^{48}$ Ellison, Foreign Influence in Samoa, p. 64; Joseph W. Ellison, "The Adventures of an American Premier in Samoa, 1874-1876," Pacific Northwest Quarterly 37 (October 1936), 323; Ryden, pp. 130-134, 136-137; and Brookes, International Rivalry, p. 339.

49 Proceedings at the meeting at Milinuu 24 December 1875 , Steinberger to Fish, and Disposition of John Coleman as to the seizure of the yacht Peerless, 8 January 1876 , Steinberger in Samoa Report, pp. 8, 33, 51. See also Daily Alta California, 13 April 1876; New York World, 20 April 1876; and Communications From Special Agents, RG 59, NA.

${ }^{50}$ Steinberger to C. E. Stevens, 20 December 1875 ; Steinberger to S. S. Foster, 21 December 1875; Demand of the King of Samoa for the surrender of arms, \& etc., taken from the yacht Peerless in the Port of Apia, Steinberger in Samoa Report, pp. 51-52, 64, 87; and Communications From Special Agents, RG 59, NA.

${ }^{51}$ Barracouta investigation (second day), Steinberger in Samoa Report, p. 17; and Communications From Special Agents, RG 59, NA.

${ }^{52}$ Speech of King Malietoa, Steinberger in Samoa Report, p. 22 ; and Communications From Special Agents, RG 59, NA.

${ }^{53}$ Barracouta investigation (third day), Steinberger in Samoa Report, pp. 19-20; and Communications From Special Agents, RG 59, NA.

${ }^{54}$ Steinberger in Samoa Report, pp. 66-67, 126-127; and Communications From Special Agents, RG 59, NA.

${ }^{55}$ Steinberger in Samoa Report, pp. 68-69, 125-126; and Communications From Special Agents, RG 59, NA.

${ }^{58}$ King Malietoa's address, 8 February 1876 ; Moepan (Governor of Aana in Upolu) to Grant, 24 February 1876; and Steinberger to Fish, I June 1876, Steinberger in Samoa Report, pp. 70-71, 79-80, 138-139; and Communications From Special Agents, RG 59, NA. See also New York Times, 7 May 1876; New York World, I4 May 1876; Daily Alta California, II March 1876; and Charles Callan Tansill, The Foreign Policy of Thomas F. Bayard I885-1897 (New York: Fordham University Press, 1940), p. Io.

${ }^{57} \mathrm{Mr}$. Ogden to the President, 5 May 1876 , The Taimua to the President, I May 1876 , Steinberger in Samoa Report, pp. $7 \mathrm{I}-72,76$; and Communications From Special Agents, RG 59, NA. See also the Times of London, 8 May, 27 May, 28 May 1876 ; New York Times, I5 June I876; and New York World, 6 May, 6 June 1876.

${ }^{58}$ References to Latrobe's various titles and his removal from Samoa are found in, Baltimore Gazette, 25 April 1876; and Baltimore Sun, 24 July 1882. Latrobe is also referred to as Mayor Latrobe, aid to the King; Judge; Major Latrobe; and Major Commander of Samoan Forces. Steinberger in Samoa Report, pp. 7, I I, I8, 23, 29 $42,67,148$.

59 Steinberger to Fish, 7 April 1876, I June 1876, Steinberger in Samoa Report, pp. 77-84; and Communications From Special Agents, RG 59, NA. There is no 
mention of the incident in J. K. Chapman, The Career of Arthur Hamilton Gordon: First Lord Stanmore I829-1912 (Toronto: University of Toronto Press, 1964).

${ }^{60}$ Ryden, Foreign Policy, p. 146; and Ward, British Policy in the South Pacific, pp. 214-215.

${ }^{61} \mathrm{~J}$. A. Campbell to Gilderoy Griffin, 23 June 1876, Steinberger in Samoa Report, p. 155 ; Morrell, Britain in the Pacific Islands, p. 218 ; Ryden, Foreign Policy, pp. 146, 156; and Ward, British Policy in the South Pacific, p. 215.

${ }^{62}$ Auckland Daily Southern Cross, 8 May 1876; The Australian, 20 May 1876; New Zealand Herald, iо May, 3 June 1876; Times of London, 27 May 1876; Ellison, Foreign Influence in Samoa, pp. 75-77; and Ellison, "The Adventure of an American in Samoa," pp. 337-339.

${ }^{63}$ New York World, 12 March 1876.

${ }^{64}$ Ibid., 20 April 1876.

${ }^{65}$ The Babcock connection is discussed in the Buffalo News, 14 April, 17 April 1876 ; Harrisburg, Pennsylvania Patriot, 15 April 1876; New York Sun, 17 April 1876; New York Times, 14 April 1876; New York World, 26 April 1876; Pueblo, Colorado Chieftain, 20 April 1876; and C. Brunsdon Fletcher, The Problem of the Pacific (New York: Henry Holt and Company, 19r9), p. 80. For the most insightful comments on Steinberger's relationship with Babcock see Rigby, "Private Interests", pp. 82-84. Articles attributing Steinberger's downfall to his love for Samoan Princess Safua are found in the New York World, 8 May 1876; and San Francisco Chronicle 30 April 1876 .

${ }^{66}$ New York Times, 5 May 1876. See also New York Times, I4 April 1876.

${ }^{67}$ Nation 22 (27 April 1876), 271.

${ }^{68}$ New York Sun, 12 March 1876; and New York Herald, 26 March 1876. See also San Francisco Daily Alta California, 15 April 1876.

${ }^{69}$ San Francisco Daily Alta California, 24 April, 7 May 1876. See also ibid., 5 April, 6 May 1876.

${ }^{70} \mathrm{~S}$. S. Foster to William Hunter, 18 March 1876 , Steinberger in Samoa Report, p. 128; and Ryden, Foreign Policy, p. 144.

${ }^{71}$ Steinberger to Fish, I June 1876, Steinberger in Samoa Report, pp. 83-84.

${ }^{72}$ Taimua and Faipule to the President, I May 1876 , ibid., p. 72.

${ }^{73}$ New York Times, 7 August 1876.

${ }^{74}$ New York World, 16 March 1876.

${ }^{75}$ Boston Evening Transcript, 3 May 1894; Boston Daily Advertiser, 4 May 1894; Harrisburg, Pennsylvania Patriot, 4 May 1894; New York Times, 4 May 1894; and Rochester, New York Union and Advertiser, 5 May 1876.

${ }^{76}$ Boston Daily Globe, 4 May r 894; Boston Evening Transcript, 3 May 1894; and Boston Herald, 4 May I894. See also New York City Directory I880-8I (New York: The Trow City Directory Company, I882), p. 1487.

${ }^{77}$ Pueblo, Colorado Chieftain, 29 July 1886 . Two of the more comprehensive encyclopedias which contain biographies of Steinberger make no mention of his life from I 876 until his death in May 1894. Appleton's Annual Cylcopedia and Register of Important Events of the Year I894 (New York: D. Appleton and Company, 1895), $X I X, 600$; and Benson John Lossing, ed., Harper's Encyclopedia of United States History, Io vols. (New York: Harper \& Brothers Publishers, I902), VIII, 404-405.

${ }^{78}$ Harrisburg, Pennsylvania Patriot, 4 May 1894.

${ }^{79}$ The best biographical sketches of William Henry Webb are found in Robert Greenhalgh Albion, "William Henry Webb," in Dumas Malone, ed., Dictionary of American Biography, 12 vols. (New York: Charles Scribner's Sons, 1927-1958); 
Henry Hall, ed. America's Successful Men of Affairs, 2 vols. (New York: 1895), pp. 704-705; and Lyman Horace Weeks, Prominent Families of New York (New York: The Historical Company, 1897), pp. 609-610.

80 The gambling note is mentioned in the New York Sun, 29 July 1875,12 March, 17 April 1876; San Francisco Chronicle, 29 July 1875; San Francisco Daily Evening Post, 31 July 1875 ; and "The Threatened Fall of Steinberger in Samoa," Frank Leslie's Illustrated Newspaper, I April 1876, p. 54.

${ }^{81}$ A brief discussion of the confusion surrounding Steinberger's title is found in Torodash, "Steinberger in Samoa," p. 52.

${ }^{82}$ Griffin to Fish, 2 February 1877 , Steinberger in Samoa Report, p. 156. Several scholars have looked positively upon his accomplishments. See Torodash, "Steinberger in Samoa," p. 52.

${ }^{83}$ Samoa Report; and Steinberger in Samoa Report.

${ }^{84}$ U.S. Congress, Senate, Committee on Foreign Relations, Report (Executive No. 3), 5oth Cong., Ist sess., 1888, S. Mis. Doc. 109, pp. 103-104, 1 10-1 34 (Serial no. 2517). See also Maurice Waters, The Ad Hoc Diplomat: A Study in Municipal and International Law (The Hague: Martinus Nijhoff, 1963), p. v.

${ }^{85}$ Waters, The Ad Hoc Diplomat, p. v. 